\title{
Down-regulation of $p$-coumaroyl
} quinate/shikimate $3^{\prime}$-hydroxylase $\left(\mathrm{C}^{\prime} \mathrm{H}\right)$ and cinnamate 4-hydroxylase $(\mathrm{C} 4 \mathrm{H})$ genes in the lignin biosynthetic pathway of Eucalyptus urophylla $\times$ E. grandis leads to improved sugar release

\author{
Robert W. Sykes ${ }^{1 *}$, Erica L. Gjersing ${ }^{1}$, Kirk Foutz ${ }^{3}$, William H. Rottmann ${ }^{3}$, Sean A. Kuhn ${ }^{3}$, Cliff E. Foster ${ }^{4}$, \\ Angela Ziebell', Geoffrey B. Turner ${ }^{2}$, Stephen R. Decker ${ }^{2}$, Maud A. W. Hinchee ${ }^{3}$ and Mark F. Davis ${ }^{1}$
}

\begin{abstract}
Background: Lignocellulosic materials provide an attractive replacement for food-based crops used to produce ethanol. Understanding the interactions within the cell wall is vital to overcome the highly recalcitrant nature of biomass. One factor imparting plant cell wall recalcitrance is lignin, which can be manipulated by making changes in the lignin biosynthetic pathway. In this study, eucalyptus down-regulated in expression of cinnamate 4-hydroxylase $\left(\mathrm{C} 4 \mathrm{H}, \mathrm{EC}\right.$ 1.14.13.11) or $p$-coumaroyl quinate/shikimate $3^{\prime}$-hydroxylase $\left(\mathrm{C} 3^{\prime} \mathrm{H}, \mathrm{EC}\right.$ 1.14.13.36) were evaluated for cell wall composition and reduced recalcitrance.

Results: Eucalyptus trees with down-regulated $\mathrm{C} 4 \mathrm{H}$ or $\mathrm{C}^{\prime} \mathrm{H}$ expression displayed lowered overall lignin content. The control samples had an average of $29.6 \%$, the $C 3^{\prime} H$ reduced lines had an average of $21.7 \%$, and the $\mathrm{C} 4 \mathrm{H}$ reduced lines had an average of $18.9 \%$ lignin from wet chemical analysis. The $\mathrm{C}^{\prime} \mathrm{H}$ and $\mathrm{C} 4 \mathrm{H}$ down-regulated lines had different lignin compositions with average $\mathrm{S} / \mathrm{G} / \mathrm{H}$ ratios of 48.5/33.2/18.3 for the $\mathrm{C} 3^{\prime} \mathrm{H}$ reduced lines and 59.0/39.8/1.2 for the $\mathrm{C} 4 \mathrm{H}$ reduced lines, compared to the control with 65.9/33.2/1.0. Both the $\mathrm{C} 4 \mathrm{H}$ and $\mathrm{C} 3^{\prime} H$ down-regulated lines had reduced recalcitrance as indicated by increased sugar release as determined using enzymatic conversion assays utilizing both no pretreatment and a hot water pretreatment.

Conclusions: Lowering lignin content rather than altering sinapyl alcohol/coniferyl alcohol/4-coumaryl alcohol ratios was found to have the largest impact on reducing recalcitrance of the transgenic eucalyptus variants. The development of lower recalcitrance trees opens up the possibility of using alternative pretreatment strategies in biomass conversion processes that can reduce processing costs.
\end{abstract}

Keywords: Eucalyptus urophylla $\times$ E. grandis, Recalcitrance, Genetic modification, Lignin biosynthesis, Pretreatment

\section{Background}

Commercial feedstocks for conversion to ethanol have traditionally been limited to corn starch and sugarcane,

\footnotetext{
*Correspondence: robert.sykes@nrel.gov

${ }^{1}$ National Bioenergy Center, National Renewable Energy Laboratory,

15013 Denver West Parkway, Golden, CO 80401-3393, USA

Full list of author information is available at the end of the article
}

but the use of food crop feedstocks has generated concern due to their important role in the world food supply [1]. Cellulosic ethanol, produced from trees, biomass residues, and herbaceous and other non-food-source biomass is a sustainable alternative that does not use feedstocks that would otherwise compete with existing food supplies. However, using lignocellulosic feedstocks 
is hampered by the higher recalcitrance to ethanol bioconversion caused by the inaccessibility of the carbohydrate substrate due to the complex nature of the plant cell wall $[2,3]$ that contributes to its natural ability to resist decomposition by enzymes [2, 4, 5]. Transgenic plants with modified cell walls may provide a source of alternative lignocellulosic feedstock. Developing chemical processes to overcome recalcitrance and improve ethanol yields from lignocellulosic materials by improving conversion efficiencies is an ongoing area of research [6]. Recently, understanding the recalcitrant nature of biomass by exploring genetically modified feedstocks that can be more easily converted to biofuels has been explored [7-11].

One of the major contributors to biomass recalcitrance is believed to be the lignin present within the cell wall [2]. Lignin is essential to the plant as it provides the structure to cell walls and provides a barrier to natural plant pathogens. Lignin is formed by the polymerization of a combination of sinapyl alcohol (S), coniferyl alcohol (G), and 4-coumaryl alcohol (H) subunits (Fig. 1) [12]. The relative levels of $\mathrm{S}, \mathrm{G}$, and $\mathrm{H}$ lignin subunits are expressed as the $\mathrm{S} / \mathrm{G} / \mathrm{H}$ ratio. However, since $\mathrm{H}$ subunits are not found in significant amounts in woody species, the ratio of lignin subunits is typically expressed as the S/G ratio. $\mathrm{H}$ lignin is only present in very low levels in most plants, such as alfalfa (Medicavo sativa) $=4.9 \%$ [7], Norway spruce (Picea abies) $=0.8 \%$ [13], and hybrid poplar $($ Populus alba $\times$ P. grandidentata $)=0.2 \%$ [14]. Lignin content, structure, and the ratio of the lignin precursors may impact the ability of enzymes to access the carbohydrates contained in the cell wall in biochemical processing using pretreatment to increase accessibility $[3,7,10$, 15]. Understanding the role of lignin content, structure, and molecular weight can identify ways to reduce the recalcitrant nature of biomass, minimize or eliminate

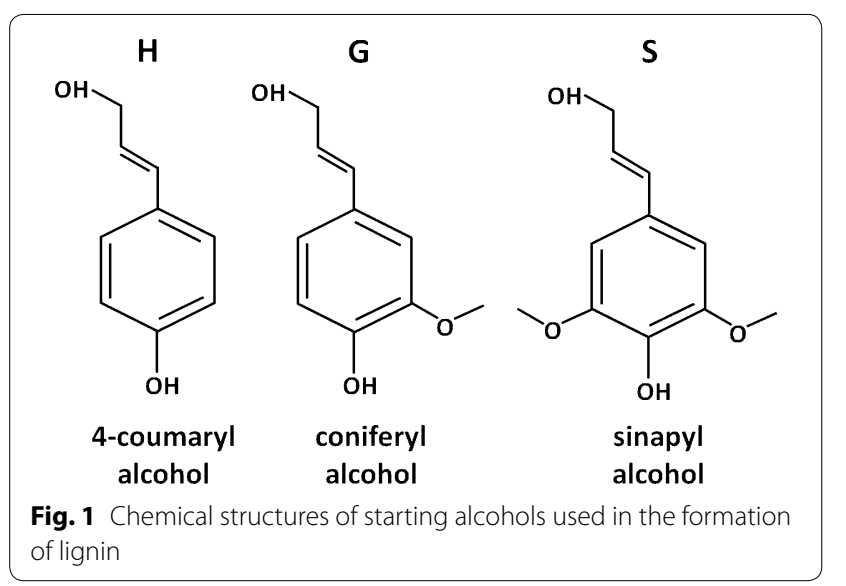

pretreatment, and facilitate the development of costeffective biochemical conversion processes for producing biofuels.

Plantation-grown trees, especially eucalyptus grown in Brazil, are already bioprocessed to produce chemical cellulose and pulp. Eucalyptus is considered the most productive tree for pulpwood production due to its biomass production rate and the properties of its wood. Improving the genetics of eucalyptus to improve pulping efficiency is a goal of the forest products industry, including traditional breeding [16], marker-assisted breeding [17], and genetically modified trees to reduce lignin content [18] and alter lignin monomer composition [19]. Advances in biotechnology have lowered the costs of gene mutation and genetic modification in trees. This has allowed tree improvement researchers to conduct functional screening of large numbers of transgenic trees a year in order to identify genetic approaches that alter cell wall composition and/or biopolymer structure, some leading to plants with lower recalcitrance. Reducing the lignin content of trees can result in lower chemical bleaching costs during the pulp and paper processing, which has provided a major impetus for exploring natural populations to identify trees with mutations in the lignin biosynthetic pathway. The lignin biosynthetic pathway has been extensively studied and there are a variety of avenues to explore when attempting to reduce plant cell wall recalcitrance [20]. Caffeic acid 3-O-methyltransferase (COMT) down-regulation has led to increased saccharification in sorghum (Sorghum bicolor (L.) Moench) [21], switchgrass (Panicum virgatum) [8], and alfalfa $(M$. sativa) [7]. Reduced recalcitrance lines have also demonstrated increased ethanol production in switchgrass lines in which COMT expression has been altered [22] and in poplar with down-regulated $p$-coumarate 3-hydroxylase or over-expressed ferulate 5-hydroxylase [10].

Cinnamate 4-hydroxylase (C4H, EC 1.14.13.11) and p-coumaroyl quinate/shikimate $3^{\prime}$-hydroxylase $\left(\mathrm{C}^{\prime} \mathrm{H}\right.$, EC 1.14.13.36) are involved near the beginning of the lignin biosynthetic pathway and their down-regulation is, therefore, expected to reduce overall lignin content and potentially impact the S/G ratio [23, 24]. Many prior publications have referred to the latter enzyme as $p$-coumarate 3-hydroxylase; in this paper, $\mathrm{C} 3^{\prime} \mathrm{H}$ is being used to mean either possibility. In alfalfa, down-regulation of the $\mathrm{C}^{\prime} \mathrm{H}$ gene decreased lignin content, increased $\mathrm{H}$ lignin monomers, and decreased molecular weight, but caused little change in the $\mathrm{S} / \mathrm{G}$ ratio $[25,26]$. In a second alfalfa study, $C 4 H$ down-regulated plants not only displayed lower lignin values, but also demonstrated reduced S/G ratios [27]. One notable difference between $C 3^{\prime} H$ and $\mathrm{C} 4 \mathrm{H}$ down-regulation in alfalfa occurs in the $\mathrm{H}$ lignin content, where plants with altered $C 3^{\prime} H$ expression 
produced a large increase in $\mathrm{H}$ lignin, but plants with altered $\mathrm{C} 4 \mathrm{H}$ expression displayed no significant change from the control. In poplar plants down-regulated in $\mathrm{C} 3^{\prime} \mathrm{H}$ expression, total lignin decreased and $\mathrm{H}$ lignin increased while S/G ratios increased [14]. Down-regulation of $\mathrm{C} 4 \mathrm{H}$ in tobacco (Nicotiana tabacum) displayed decreases in total lignin and slight decreases in S/G [28]. This paper deals with transgenic lines of hybrid eucalyptus (Eucalyptus urophylla $\times$ E. grandis) exhibiting downregulated $C 4 H$ or $C 3^{\prime} H$ expression. Specifically, the trees were transformed using RNA interference (RNAi) constructs directed against $\mathrm{EgrC4H1}$, the gene encoding the most strongly xylem-expressed $\mathrm{C} 4 \mathrm{H}$, or $\operatorname{EgrC} 3^{\prime} H 3$, the gene encoding the most strongly xylem-expressed $\mathrm{C}^{\prime} \mathrm{H}$ [29].

\section{Results and discussion Selection of lines}

After generating and field testing multiple lines of eucalyptus transformed using plasmids designed to reduce lignin content, wood from the trees was characterized by pyrolysis molecular beam mass spectrometry (PyMBMS) to identify lines with moderate levels of lignin reduction (approximately $30 \%$ reduction). A subset of selected lines was established in a greenhouse, grown for 6 months, and characterized using quantitative polymerase chain reaction (qPCR) to verify that the target genes were indeed reduced in expression (Table 1). Four lines transformed using the pARB670 plasmid (EgrC4H1 down-regulation) had an average $E g r C 4 H 1$ RNA expression level of $9.5 \pm 1.0 \%$ of that found in control samples, with a mild reduction of $\mathrm{EgrC}^{\prime} \mathrm{H} 3$ expression to $75 \pm 6 \%$ of control

Table 1 RT-PCR quantification of gene expression

\begin{tabular}{lll}
\hline Sample & $\begin{array}{l}\text { Relative expression of } \\
\text { C4H (Eucgr.H01844) }\end{array}$ & $\begin{array}{l}\text { Relative expression of } \\
\text { C3H (Eucgr.A02190) }\end{array}$ \\
\hline Control 014 & 0.95 & 0.85 \\
Control 018 & 0.98 & 1.08 \\
Control 023 & 1.06 & 1.03 \\
Control avg & $1.00 \pm 0.06$ & $0.99 \pm 0.12$ \\
C3'H 105 & 0.79 & 0.15 \\
C3'H 113 & 0.68 & 0.093 \\
$\mathrm{C}^{\prime} \mathrm{H} 114$ & 0.79 & 0.082 \\
$\mathrm{C}^{\prime} \mathrm{H}$ avg & $0.75 \pm 0.06^{*}$ & $0.108 \pm 0.036^{*}$ \\
$\mathrm{C} 4 \mathrm{H} 091$ & 0.11 & 0.76 \\
$\mathrm{C} 4 \mathrm{H} 092$ & 0.092 & 1.22 \\
$\mathrm{C} 4 \mathrm{H} 093$ & 0.091 & 0.69 \\
$\mathrm{C} 4 \mathrm{H} 098$ & 0.087 & 0.62 \\
$\mathrm{C} 4 \mathrm{H}$ avg & $0.095 \pm 0.010^{*}$ & $0.82 \pm 0.27$ \\
\hline
\end{tabular}

* Indicates significant difference from the control average at the $p$ value $<0.05$ level levels. Accordingly, three lines transformed using the pARB669 plasmid ( $\mathrm{EgrC3}^{\prime} \mathrm{H} 3$ down-regulation) had an average $\mathrm{EgrC3}^{\prime} \mathrm{H} 3 \mathrm{RNA}$ expression level of $10.8 \pm 3.6 \%$ of that found in control samples, with a nonsignificant reduction of EgrC4H1 expression. Although it was not possible to perform qPCR analysis on all lines due to losses of plants in tissue culture storage, these results suggest that the initial PyMBMS characterization allowed accurate selection of lines with the target genes reduced to similar levels.

\section{Extractives content}

Eucalyptus trees can have high levels of natural oils in the wood that could impact the methods used to determine sugar release. To remove these natural oils, a water and ethanol extraction was performed. After extraction, there was a reduction in the error associated with the sugarrelease results. Average standard deviation for the unextracted wood was $\pm 0.025 \mathrm{~g} / \mathrm{g}$, compared to $\pm 0.011 \mathrm{~g} / \mathrm{g}$ biomass for the extractives-free wood. Sugar-release results from the extractives-free wood were comparable to the unextracted wood with a $R^{2}=0.91$ (data not shown).

\section{Starch removal}

Starch content can artificially inflate sugar release results, falsely indicating lower recalcitrant samples [30]. To prevent starch content from effecting sugar release results, it can be removed. However, the starch content for all samples used in this study was determined to be lower than $1.2 \%$, with a measurement error of $1 \%$. Due to the low starch values measured, samples were run without a starch removal treatment.

\section{Cell wall composition}

The results of the cell wall compositional analysis are shown in Table 2. The down-regulation of the $C 3^{\prime} H$ and $\mathrm{C} 4 \mathrm{H}$ genes in the lignin pathway is expected to result in a reduction of the lignin precursors necessary for normal lignin biosynthesis, potentially lowering the lignin content as well as altering the $\mathrm{S} / \mathrm{G} / \mathrm{H}$ ratio. Both the $\mathrm{C}^{\prime} H$ and $C 4 H$ RNAi lines were observed to have significantly reduced lignin content compared to the untransformed control (Table 2). The $\mathrm{C}^{\prime} H$ down-regulated plants resulted in an average $26.7 \%$ reduction of lignin content, while the $C 4 H$ down-regulated plants had an average $36.1 \%$ lignin content reduction. The reduction in lignin content for $\mathrm{C3}^{\prime} H$ and $C 4 H$ down-regulated lines was consistent with the findings of Chen and Dixon [7] in alfalfa where similar genetic transformations displayed a $37 \%$ reduction for $\mathrm{C3}^{\prime} H$ antisense lines and a $29 \%$ reduction for $C 4 H$ antisense lines. In eucalyptus, the reduction in lignin content in both $\mathrm{C}^{\prime} H$ and $C 4 H$ down-regulated 
Table 2 Traditional wet chemical composition for eucalyptus plants with lignin pathway modifications

\begin{tabular}{|c|c|c|c|c|c|c|c|c|c|c|}
\hline Sample & $\%$ Ash & $\begin{array}{l}\% \text { Water } \\
\text { extractives }\end{array}$ & $\begin{array}{l}\% \text { Ethanol } \\
\text { extractives }\end{array}$ & $\%$ Lignin & $\%$ Glucose & $\%$ Xylose & $\%$ Galactose & $\%$ Arabinose & $\%$ Acetyl & $\begin{array}{l}\% \text { Mass } \\
\text { closure }\end{array}$ \\
\hline Control a & 0.5 & 4.4 & 0.9 & 29.3 & 39.4 & 13.0 & 1.7 & 0.5 & 3.9 & 93.5 \\
\hline Control b & 0.7 & 3.9 & 0.9 & 30.0 & 40.9 & 13.1 & 1.5 & 0.6 & 3.9 & 95.3 \\
\hline Control avg & 0.6 & 4.2 & 0.9 & 29.6 & 40.2 & 13.0 & 1.6 & 0.5 & 3.9 & 94.4 \\
\hline C3'H 105 & 0.7 & 7.3 & 1.2 & 22.3 & 38.8 & 16.0 & 1.4 & 0.0 & 4.7 & 92.4 \\
\hline $\mathrm{C}^{\prime} \mathrm{H} 106 \mathrm{a}$ & 0.5 & 5.7 & 1.0 & 21.3 & 41.9 & 16.3 & 1.8 & 0.6 & 4.9 & 94.0 \\
\hline $\mathrm{C}^{\prime} \mathrm{H} 106 \mathrm{~b}$ & 0.5 & 6.7 & 1.2 & 21.4 & 41.0 & 16.1 & 1.3 & 0.6 & 4.9 & 93.7 \\
\hline $\mathrm{C}^{\prime} \mathrm{H} 113 \mathrm{a}$ & 0.5 & 7.0 & 1.1 & 21.5 & 39.5 & 17.1 & 1.3 & 0.3 & 5.1 & 93.3 \\
\hline $\mathrm{C} 3^{\prime} \mathrm{H} 113 \mathrm{~b}$ & 0.5 & 6.9 & 1.3 & 22.1 & 38.5 & 17.3 & 1.3 & 0.7 & 4.9 & 93.5 \\
\hline $\mathrm{C} 3^{\prime} \mathrm{H} 114$ & 0.9 & 4.6 & 1.7 & 21.6 & 38.5 & 18.4 & 1.3 & 3.1 & 4.9 & 95.1 \\
\hline $\mathrm{C} 3^{\prime} \mathrm{H}$ avg & 0.6 & $6.4^{*}$ & 1.3 & $21.7^{*}$ & 39.7 & $16.9^{*}$ & 1.4 & 0.9 & $4.9^{*}$ & 93.7 \\
\hline $\mathrm{C} 4 \mathrm{H} 73 \mathrm{a}$ & 0.9 & 3.7 & 0.8 & 17.8 & 46.3 & 16.6 & 2.5 & 0.3 & 4.7 & 93.6 \\
\hline $\mathrm{C} 4 \mathrm{H} 73 \mathrm{~b}$ & 0.9 & 5.8 & 0.9 & 18.9 & 42.3 & 17.3 & 1.7 & 0.3 & 4.9 & 92.8 \\
\hline $\mathrm{C} 4 \mathrm{H} 91$ & 0.8 & 3.8 & 0.9 & 20.9 & 43.5 & 16.6 & 1.8 & 2.5 & 4.2 & 95.0 \\
\hline $\mathrm{C} 4 \mathrm{H} 92$ & 0.8 & 3.8 & 1.0 & 19.5 & 44.0 & 17.7 & 1.4 & 2.7 & 4.5 & 95.4 \\
\hline $\mathrm{C} 4 \mathrm{H} 93$ & 0.7 & 4.7 & 0.8 & 18.5 & 42.7 & 18.5 & 1.9 & 2.6 & 4.7 & 95.2 \\
\hline $\mathrm{C} 4 \mathrm{H} 96$ & 0.7 & 5.8 & 0.8 & 17.5 & 41.3 & 19.0 & 1.4 & 0.1 & 5.2 & 91.9 \\
\hline $\mathrm{C} 4 \mathrm{H} 98$ & 0.8 & 3.9 & 1.0 & 20.1 & 43.5 & 17.5 & 1.7 & 2.2 & 4.3 & 95.0 \\
\hline $\mathrm{C} 4 \mathrm{H} 99 \mathrm{a}$ & 0.8 & 4.4 & 1.3 & 18.5 & 41.6 & 18.3 & 1.6 & 0.4 & 4.9 & 91.9 \\
\hline $\mathrm{C} 4 \mathrm{H} 99 \mathrm{~b}$ & 0.9 & 5.3 & 1.0 & 18.4 & 42.0 & 17.6 & 1.6 & 0.3 & 4.7 & 91.9 \\
\hline $\mathrm{C} 4 \mathrm{H}$ avg & $0.8^{*}$ & 4.6 & 0.9 & $18.9^{*}$ & 43.0 & $17.7^{*}$ & 1.7 & 1.3 & $4.7^{*}$ & 93.6 \\
\hline
\end{tabular}

* Indicates significant difference from the control average at the $p$ value $<0.05$ level

lines was offset by increases in the measured extractives, xylose, and acetyl contents (Table 2). Average glucose content of the $C 4 H$ down-regulated lines (43.0\%) was increased compared to the control (40.2\%), while the glucose content for the $C 3^{\prime} H$ down-regulated lines was relatively unchanged (39.7\%) (Table 2). Galactose contents for both $\mathrm{C3}^{\prime} \mathrm{H}$ and $\mathrm{C} 4 \mathrm{H}$ down-regulated lines remained relatively unchanged compared to the control. The increase in xylose and acetyl content for both $C 3^{\prime} H$ and $\mathrm{C} 4 \mathrm{H}$ RNAi lines is consistent with $\mathrm{O}$-acetyl-(4-Omethylglucurono)xylan, the primary hardwood hemicellulose, comprising a larger fraction of the cell wall. There was a decrease in arabinose content for the $\mathrm{C} 4 \mathrm{H}$ downregulated lines, although the arabinose levels measured were close to the detection level of the analytical methods used in the analysis.

Thioacidolysis and PyMBMS were used to characterize changes in lignin structure and to measure the relative amounts of subunits in the lignin polymer. Thioacidolysis determined average $\mathrm{S} / \mathrm{G}$ ratios of $1.5,1.5$, and 2.0 for the $C 3^{\prime} H$ reduced, $C 4 H$ reduced, and control samples, respectively (Table 3 ). Thioacidolysis measured a significant increase in the $\mathrm{H}$ monomers released in the $C 3^{\prime} H$ down-regulated lines, indicating that a larger fraction of lignin is the 4-coumaryl alcohol $(\mathrm{H})$ subunit. The increase in $\mathrm{H}$ monomers is consistent with impeding the conversion of $p$-coumaroyl quinate/shikimate to caffeoyl quinate/shikimate by down-regulation of the $C 3^{\prime} H$ gene, reducing the formation of the monolignols necessary for $\mathrm{G}$ lignin and $\mathrm{S}$ lignin, while increasing the monolignols necessary for $\mathrm{H}$ lignin (see Bonawitz and Chapple [20] for a schematic of the lignin biosynthetic pathway). These results follow the same trend that was previously observed in alfalfa [27], where control and $C 4 H$ downregulated plants displayed similar $\mathrm{H}$ lignin levels of 3-4 \% and the $C 3^{\prime} H$ down-regulated lines displayed $48 \% \mathrm{H}$ lignin. PyMBMS confirmed that there was a reduction in the ratio of the syringyl to guaiacyl monomers from 2.1 in the control samples to 1.2 in both the $C 3^{\prime} H$ and C4H RNAi lines (Table 3). PyMBMS did not detect an increase in molecular fragments that are associated with $\mathrm{H}$ lignin in the $C 3^{\prime} H$ RNAi lines. It was determined that the non-pyrolyzed char content was highly correlated to the amount of $\mathrm{H}$ lignin as determined by thioacidolysis, indicating that the $\mathrm{H}$ lignin fraction was not fragmenting to smaller molecules during pyrolysis and, therefore, was not detected (data not shown). Previous ${ }^{13} \mathrm{C}$ nuclear magnetic resonance $\left({ }^{13} \mathrm{C}\right.$-NMR) analyses of lignin isolated from $C 3^{\prime} H$ down-regulated lines in alfalfa have determined that there is a greater prevalence of $\mathrm{C}-\mathrm{C}$ bonds in 
Table 3 Thioacidolysis results compared with lignin and S/G estimates using pyrolysis molecular beam mass spectrometry (PyMBMS)

\begin{tabular}{|c|c|c|c|c|c|c|}
\hline \multirow[t]{2}{*}{ Sample } & \multicolumn{4}{|c|}{ Thioacidolysis } & \multicolumn{2}{|l|}{ PyMBMS } \\
\hline & $\% \mathrm{~S}$ & $\%$ G & $\% \mathbf{H}$ & S/G Ratio & S/G Ratio & Lignin \\
\hline Control a & 66.0 & 32.6 & 1.5 & 2.0 & 2.1 & 30.0 \\
\hline Control b & 65.8 & 33.7 & 0.5 & 1.9 & 2.1 & 30.9 \\
\hline Control avg & 65.9 & 33.2 & 1.0 & 2.0 & 2.1 & 30.4 \\
\hline C3'H 105 & 51.7 & 34.0 & 14.2 & 1.5 & 1.4 & 22.9 \\
\hline $\mathrm{C} 3^{\prime} \mathrm{H} 106 a$ & 48.3 & 34.2 & 17.6 & 1.4 & 1.2 & 20.5 \\
\hline$C 3^{\prime} H$ 106b & 46.9 & 34.2 & 19.0 & 1.4 & 1.1 & 21.2 \\
\hline $\mathrm{C} 3^{\prime} \mathrm{H} 113 \mathrm{a}$ & 49.1 & 32.4 & 18.5 & 1.5 & 1.2 & 21.5 \\
\hline$C 3^{\prime} \mathrm{H} 113 \mathrm{~b}$ & 48.8 & 31.2 & 19.9 & 1.6 & 1.2 & 20.6 \\
\hline $\mathrm{C} 3^{\prime} \mathrm{H} 114$ & 46.1 & 33.5 & 20.4 & 1.4 & 1.1 & 19.6 \\
\hline $\mathrm{C} 3^{\prime} \mathrm{H}$ avg & $48.5^{*}$ & 33.2 & $18.3^{*}$ & $1.5^{*}$ & $1.2^{*}$ & $21.0^{*}$ \\
\hline $\mathrm{C} 4 \mathrm{H} 73 \mathrm{a}$ & 58.6 & 38.2 & 3.1 & 1.5 & 1.2 & 21.9 \\
\hline $\mathrm{C} 4 \mathrm{H} 73 \mathrm{~b}$ & 59.0 & 40.2 & 0.9 & 1.5 & 1.2 & 21.9 \\
\hline $\mathrm{C} 4 \mathrm{H} 91$ & 57.7 & 41.4 & 0.9 & 1.4 & 1.3 & 23.1 \\
\hline $\mathrm{C} 4 \mathrm{H} 92$ & 58.2 & 41.2 & 0.7 & 1.4 & 1.3 & 22.5 \\
\hline $\mathrm{C} 4 \mathrm{H} 93$ & 59.2 & 39.7 & 1.1 & 1.5 & 1.2 & 21.1 \\
\hline $\mathrm{C} 4 \mathrm{H} 96$ & 58.4 & 40.8 & 0.8 & 1.4 & 1.2 & 21.8 \\
\hline $\mathrm{C} 4 \mathrm{H} 98$ & 61.5 & 37.6 & 0.9 & 1.6 & 1.3 & 22.9 \\
\hline C4H 99a & 60.4 & 38.5 & 1.2 & 1.6 & 1.1 & 19.0 \\
\hline C4H 99b & 58.0 & 40.9 & 1.0 & 1.4 & 1.1 & 21.2 \\
\hline $\mathrm{C} 4 \mathrm{H}$ avg & $59.0^{*}$ & $39.8^{*}$ & 1.2 & $1.5^{*}$ & $1.2^{*}$ & $21.7^{*}$ \\
\hline
\end{tabular}

* Indicates significant difference from the control average at the $p$ value $<0.05$ level

$\mathrm{H}$ lignin that would remain intact at the pyrolysis temperatures used in this study [31].

\section{Reduced recalcitrance}

Wood samples were analyzed using a high-throughput pretreatment and enzymatic saccharification process to determine if the $\mathrm{C3}^{\prime} \mathrm{H}$ and $\mathrm{C} 4 \mathrm{H}$ gene expression modifications lowered recalcitrance [32, 33]. Reduced recalcitrance is defined as an increase in glucose and xylose release after enzymatic saccharification compared to the control samples under a defined pretreatment condition. The cell wall chemistry data of the sugar content in the biomass allowed the sugar release data to be converted to a percent release for both non-pretreated and pretreated samples. For samples not subjected to pretreatment, the $C 4 H$ reduced lines released an average $21 \%$ of the total sugar, which was a significant improvement over the control samples that displayed an average of only $2 \%$ of the total sugars released, while the $C 3^{\prime} H$ reduced lines averaged a $16 \%$ release (Table 4 ). Chen and Dixon [7] also found decreased recalcitrance in alfalfa lines with down-regulated $C 3^{\prime} H$ expression, with enzymatic hydrolysis efficiency approximately twice that of the controls for the $C 3^{\prime} H$ antisense lines and 1.5 times the control for the $\mathrm{C} 4 \mathrm{H}$ antisense lines. In the present study on eucalyptus, hot water pretreated samples displayed an average percent total sugar release for the control of $80 \%$, while the $C 3^{\prime} H$ down-regulated lines released $94 \%$ of the total sugars and the $\mathrm{C} 4 \mathrm{H}$ lines $97 \%$. By providing a near $100 \%$ release upon pretreatment, these lines have high potential for bioconversion. Plants requiring decreased or no pretreatment are of interest for the biofuel industry because pretreatment is often one of the most costly aspects of fuel production due to chemical costs, sugar degradation products that can inhibit fermentations, and capital costs [6].

However, genetically modified plants with strong lignin reduction typically result in reduced growth, which decreases per-acre crop yields [20], and the mechanisms behind this are still being investigated [34]. While the $C 3^{\prime} H$ down-regulated lines exhibited severely reduced growth (average height $2.0 \mathrm{~m}$ compared to $6.0 \mathrm{~m}$ for the control), the $C 4 H$ down-regulated lines showed a milder effect (average height $3.4 \mathrm{~m}$ ); and there were no obvious pest problems observed for the reduced-lignin lines. It may be possible to mitigate the negative growth effect through cultural treatments such as irrigation or coppicing. In addition, more refined lignin modification constructs that protect the integrity of vessel walls could to be other pathways toward the protection of yield. A 
Table 4 Percentage of sugar released by enzymatic saccharification

\begin{tabular}{|c|c|c|c|c|c|c|}
\hline \multirow[t]{2}{*}{ Sample } & \multicolumn{3}{|c|}{ No pretreatment } & \multicolumn{3}{|c|}{ Hydrothermal pretreatment } \\
\hline & $\%$ Glucose & $\%$ Xylose & $\%$ Total & $\%$ Glucose & $\%$ Xylose & $\%$ Total \\
\hline Control a & 3 & 1 & 3 & 72 & 97 & 78 \\
\hline Control b & 1 & 2 & 1 & 73 & 108 & 82 \\
\hline Control avg & 2 & 1 & 2 & 73 & 102 & 80 \\
\hline C3'H 105 & 11 & 9 & 11 & 89 & 111 & 95 \\
\hline $\mathrm{C} 3^{\prime} \mathrm{H} 106 \mathrm{a}$ & 17 & 11 & 15 & 86 & 106 & 92 \\
\hline $\mathrm{C} 3^{\prime} \mathrm{H} 106 \mathrm{~b}$ & 16 & 13 & 15 & 86 & 110 & 92 \\
\hline $\mathrm{C} 3^{\prime} \mathrm{H} 113 \mathrm{a}$ & 16 & 11 & 14 & 87 & 109 & 93 \\
\hline$C 3^{\prime} \mathrm{H} 113 \mathrm{~b}$ & 16 & 13 & 15 & 90 & 110 & 96 \\
\hline $\mathrm{C} 3^{\prime} \mathrm{H} 114$ & 29 & 25 & 28 & 82 & 97 & 87 \\
\hline$C 3^{\prime} \mathrm{H}$ avg & $18^{*}$ & $14^{*}$ & $16^{*}$ & $87^{*}$ & 107 & $93^{*}$ \\
\hline $\mathrm{C} 4 \mathrm{H} 73 \mathrm{a}$ & 30 & 21 & 28 & 82 & 103 & 88 \\
\hline $\mathrm{C} 4 \mathrm{H} 73 \mathrm{~b}$ & 18 & 14 & 17 & 94 & 113 & 99 \\
\hline $\mathrm{C} 4 \mathrm{H} 91$ & 12 & 9 & 11 & 88 & 107 & 93 \\
\hline $\mathrm{C} 4 \mathrm{H} 92$ & 15 & 11 & 14 & 89 & 103 & 93 \\
\hline $\mathrm{C} 4 \mathrm{H} 93$ & 26 & 17 & 23 & 94 & 105 & 97 \\
\hline $\mathrm{C} 4 \mathrm{H} 96$ & 23 & 16 & 21 & 96 & 103 & 98 \\
\hline $\mathrm{C} 4 \mathrm{H} 98$ & 22 & 12 & 19 & 84 & 96 & 87 \\
\hline C4H 99a & 30 & 22 & 28 & 98 & 111 & 102 \\
\hline C4H 99b & 28 & 23 & 26 & 93 & 109 & 98 \\
\hline $\mathrm{C} 4 \mathrm{H}$ avg & $23^{*}$ & $16^{*}$ & $21^{*}$ & $91^{*}$ & 106 & $95^{*}$ \\
\hline
\end{tabular}

* Indicates significant difference from the control average at the $p$ value $<0.05$ level

promoter with expression restricted to fibers might be used in down-regulation constructs. Another alternative might be introduction of a $\mathrm{C} 4 \mathrm{H}$ gene under control of a vessel-specific promoter in combination with downregulation or mutation of the more generally expressed endogenous $\mathrm{C} 4 \mathrm{H}$ gene [35]. Despite the slower growth, the $C 4 H$ down-regulated wood responded well to a mild hot water pretreatment; therefore, the reduced lignin trees may still provide economic benefit. Hot water pretreatment has the potential to significantly lower the cost associated with biomass pretreatment due to a reduction in chemical usage, lower amounts of sugar degradation products that can inhibit fermentation, and capital costs compared to other pretreatment technologies, such as dilute acid, alkali, and steam explosion [32, 33].

The results of this study determined that lignin content has a large impact on lowering recalcitrance, as shown by the correlation between Klason lignin content and the percentage of glucose released after pretreatment and enzymatic hydrolysis (Fig. 2). The down-regulation of the $\mathrm{C} 4 \mathrm{H}$ gene produced trees that had an average Klason lignin content of $17.8 \%$ and released $91 \%$ of the available glucose compared to $73 \%$ for the control under identical pretreatment conditions. The low lignin lines also released significantly more sugar without pretreatment, although pretreatment is still necessary to release

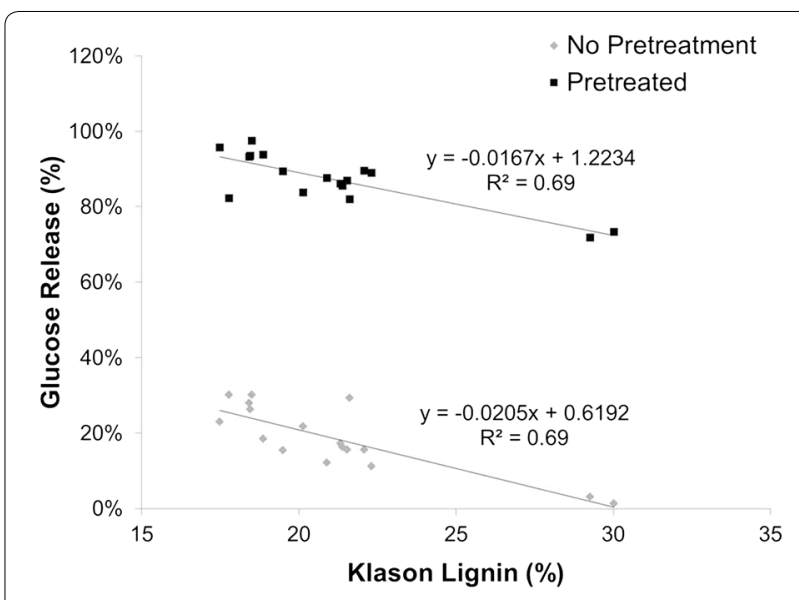

Fig. 2 Glucose release versus Klason lignin content for samples that were not subjected to pretreatment (gray diamonds) and pretreated samples (black squares)

enough sugar to make these transgenic lines candidates for biofuel production. These results agree well with published data on alfalfa where lignin levels were observed to correlate with sugar release [7]. Reducing recalcitrance by reducing lignin content was also reported by $\mathrm{Fu}$ et al. [8] via an ethanol assay with COMT down-regulated switchgrass, where a $12-15 \%$ reduction in lignin content 
resulted in an increased ethanol yield of up to $38 \%$ over the control.

With the strong correlation between lignin content and glucose release, the question is raised as to whether the reduction in recalcitrance is also associated with the lignin structure. The wood samples produced by downregulation of either the $C 4 H$ or $C 3^{\prime} H$ genes have similar S/G ratios, 1.2 as determined by PyMBMS and 1.4 from thioacidolysis. However, the C4H RNAi lines released greater amounts of glucose than the $C 3^{\prime} H$ RNAi lines utilizing no pretreatment and hot water pretreatment. In addition, these sugar release results indicate that $\mathrm{H}$ lignin content is not, in and of itself, a primary factor in recalcitrance since the $C 3^{\prime} H$ down-regulated lines, containing $18.3 \% \mathrm{H}$ lignin (Table 3), were more recalcitrant than the $\mathrm{C} 4 \mathrm{H}$ down-regulated lines with only $1.2 \% \mathrm{H}$ lignin. Therefore, in this study, lowering lignin content appears to have had a much larger effect on reducing recalcitrance than changing the $\mathrm{H}$ lignin subunit ratio. Our results are consistent with the findings of Chen and Dixon [7], finding no real correlation between S/G ratio and sugar release for antisense $\mathrm{C}^{\prime} \mathrm{H}$ and antisense shikimate hydroxycinnamoyl transferase (HCT) low lignin transgenic lines in alfalfa. However, these eucalyptus results are not in agreement with data from natural poplar variants that were found to be less dependent on lignin content and more dependent on the $S / G$ ratio of the wood samples [32, 36].

\section{Conclusions}

Down-regulating $\mathrm{C}^{\prime} H$ and $C 4 H$ genes in the lignin biosynthetic pathway results in eucalyptus trees with lower lignin content and altered $\mathrm{S} / \mathrm{G} / \mathrm{H}$ ratios. Thioacidolysis results indicate that the $\mathrm{C}^{\prime} \mathrm{H}$ RNAi lines contain an average $18.3 \% \mathrm{H}$ lignin, while the $C 4 H \mathrm{RNAi}$ lines contain only $1.2 \%$, similar to the control samples at $1 \% \mathrm{H}$ lignin. Down-regulation of each gene led to lines with significantly reduced recalcitrance, releasing a greater amount of glucose with lower severity pretreatments. The $\mathrm{C} 4 \mathrm{H}$ down-regulated lines had particularly high sugar release, with more than half the lines achieving $90 \%$ glucose release using hot water pretreatment, with two lines having glucose release of more than $95 \%$. This study identified lowering lignin content rather than altering the $\mathrm{S} / \mathrm{G} / \mathrm{H}$ ratios had the largest impact on reducing recalcitrance of the transgenic lines. The less recalcitrant nature of the $C 3^{\prime} H$ and $C 4 H$ RNAi lines make these plants excellent candidates for biofuel feedstocks.

\section{Methods}

\section{Plant materials}

To test the effect of different target genes on reducing lignin in hybrid eucalyptus, $E$. urophylla $\times E$. grandis was transformed with two plasmids designed to reduce the expression of genes in the lignin biosynthetic pathway [37]. Gene sequence information for the E. grandis genome [38] can be obtained at the Phytozome website [39, 40]. EgrC4H1 [Phytozome:Eucgr.J01844] and EgrC3'H3 [Phytozome: Eucgr.A02190] cDNAs were isolated from xylem libraries derived from $E$. grandis. For each gene, a 600-bp fragment from the $3^{\prime}$ portion of the cDNA was cloned as an inverted repeat, driven by the promoter from a E. grandis arabinogalactan protein gene [Phytozome:Eucgr.B02846]. The xylem-preferred promoter comprised 2340 base pairs upstream of the predicted initiation codon for this gene [37]. The plasmid identities were pARB669 for $E g r C 3^{\prime} H 3$ and pARB670 for $E g r C 4 H 1$. The plasmids were introduced into an in vitro clonally propagated line of $E$. urophylla $\times E$. grandis via Agrobacterium-mediated transformation of young leaves similar to that described by Tournier et al. [41]. Fifteen independent events were generated for pARB669 and 18 events were produced for pARB670. The nontransformed line was used as the control. The plants were grown for 3 months as containerized cuttings in the greenhouse, acclimatized for 1 month outdoors, and then transferred into the field in Glades County, Florida, for an additional 20 months before destructive sampling. Stems were debarked, air dried, and milled with a Wiley mill to pass through a 20-mesh screen.

\section{Gene expression}

Gene expression was measured using real-time qPCR. For these analyses, additional plants of a subset of the lines were established in a greenhouse and grown for 6 months. Three lines transformed with a selectable marker were used as controls. Lignifying lateral branches approximately $2 \mathrm{~mm}$ in diameter were collected without removing pith or epidermis. Samples were frozen in liquid $\mathrm{N}_{2}$ and stored at $-80^{\circ} \mathrm{C}$ until RNA extraction.

Total RNA was extracted from $100 \mathrm{mg}$ samples of greenhouse-grown stem material, which had been ground to a powder with mortar, pestle, and liquid nitrogen, using the RNeasy Plant Mini Kit (QIAGEN). Potentially contaminating genomic DNA was removed from the RNA by treatment with the TURBO DNA-free Kit (Ambion). cDNA was synthesized using the Affinity Script qPCR cDNA Synthesis Kit (Stratagene), using between 20 and $100 \mathrm{ng}$ of total RNA per sample. All kits were used according to their respective manufacturer's instructions.

Quantitative PCR was performed in a 96-well format using an Agilent Technologies/Stratagene Mx3000P with an elongation factor $1 \alpha$ gene [Phytozome:Eucgr.G02807] used as the reference. The qPCR primers and probes were designed using Primer3 [42]. Primer oligonucleotides were 
synthesized by Invitrogen, and probes were synthesized by Biosearch Technologies. The primer oligonucleotides were C4H-J01844-L1 (5'-ATCTGCAAGGAGGTCAAGGA-3'), C4H-J01844-R1 (5'-CGTTGATGTTCTCGACGATG-3'), C3H-A02190-L1 (5'-GCACCAACCCTGATAATTCG-3'), C3H-A02190-R1 (5'-GACACGATCGCCTTGAACTC-3'), EFA-G02807-L2 (5'-GGGCCCCACCCTCCTCGACG CT-3'), and EFA-G02807-R1 (5'-GCCGTTGCCAATCTG CCCGGGGT- $3^{\prime}$ ). Probes for the lignin genes were $\mathrm{C} 4 \mathrm{H}-$ J01844-P1 (5'-ACTTCGTCGACGAGAGGAAA-3') and C3H-A02190-P1 (5'-TGGTGAAGAAGTACCTGG GG-3'), each labeled with 6-carboxyfluorescein. The probe for the reference gene, EFA-G02807-P2 (5'-AGGCTCTCCA GGAGGCCCTCCCT-3'), was labeled with hexachlorofluorescein.

Each $25 \mu \mathrm{L}$ reaction contained $3 \mathrm{pmol}$ of the appropriate probe oligonucleotide and 5 pmol of each corresponding primer oligonucleotide, plus $12.5 \mu \mathrm{L}$ of Maxima Probe/ROX qPCR Master Mix $(2 \times)$ (Thermo Fisher Scientific \#K0233) and cDNA equivalent to 1-5 ng of total RNA. Three plants were analyzed from each line. A single RNA purification and cDNA synthesis was done for each biological replicate and all qPCR reactions were run in duplicate. Changes in expression of the genes of interest in the RNAi lines relative to their expression in the transformed controls were calculated by the $\mathrm{ddCt}$ method [41], using the average of the $\mathrm{dCt}$ of each gene in the control lines as the baseline for that gene.

\section{Removal of extractives}

Dried biomass samples were knife milled to 60-mesh and loaded into tea bags and sealed for extraction. The samples were extracted with a 1:1 water and ethanol mixture using a soxhlet and allowed to air dry in a hood for $24 \mathrm{~h}$.

\section{Starch content}

Starch content was measured on all samples to ensure starch did not artificially contribute to the sugar release values. The starch assay was adapted from a standard commercial starch test from Megazyme International. After loading the biomass into the wells of a 96-well Hastelloy plate, each of the samples was wetted with $20 \mu \mathrm{L}$ of $80 \%$ ethanol, and $300 \mu \mathrm{L}$ of the amylase solution was added. The plates were sealed with a polypropylene adhesive seal (Titer-Tops, Diversified Biotech) augmented with custom magnetic sealing lids. The sealed plates were incubated overnight at $55^{\circ} \mathrm{C}$ and $125 \mathrm{rpm}$ in a HiGro microtiter plate incubator. Glucose analysis after amylase digestion was conducted using the glucose oxidase assay described in Selig et al. [32].

\section{Recalcitrance measurements}

Recalcitrance was determined using a high-throughput system developed at the National Renewable Energy Laboratory (NREL) for the BioEnergy Science Center as described in Selig et al. [32] and Decker et al. [33]. Briefly, control and experimental biomass samples were knife milled to pass a 20-mesh screen and then dispensed into a custom-machined, 96-well Hastelloy plates in $5.0 \pm 0.3 \mathrm{mg} /$ well aliquots using the Symyx robotic system. Triplicate samples, as well as standards and controls, were distributed across the plates. Water was added to each well $(250 \mu \mathrm{L})$, and the loaded reactor plate was sealed using silicone adhesive Teflon tape and sandwiched between two empty plates. Glass reinforced Teflon gaskets were placed between adjacent plates, and then the stack was clamped tightly using a custom clamping system. The clamped stack was then loaded into a Parr reactor electrically preheated to $180{ }^{\circ} \mathrm{C}$. Steam was introduced and the reactor assembly was held at $180{ }^{\circ} \mathrm{C}$ (as determined by a thermocouple in the reactor vessel) for $17.5 \mathrm{~min}$. Steam was then vented and cooling water was allowed to flow into the reactor. These pretreatment conditions were chosen to be suboptimal to enhance differences due to changes in the biomass recalcitrance. The suboptimal conditions were chosen to release $70 \%$ of the glucose of the standard Populus trichocarpa $\times P$. deltoides F1 hybrid, clone 53-239 sample harvested near Oak Ridge, Tennessee.

Enzymatic saccharification of the samples with no pretreatment and pretreated solids including the hydrolysate was carried out in the 96-well reactor plates. All the saccharification samples were loaded with an excess (70 $\mathrm{mg} / \mathrm{g}$ initial biomass) of a commercial enzyme preparation CTec2 (Novozyme 188, Novozymes A/S, Bagsværd, Denmark), buffered with $1 \mathrm{M}$ citrate to maintain a pH of 5.0, and incubated at $50{ }^{\circ} \mathrm{C}$ for $72 \mathrm{~h}$. Analysis of glucose and xylose released into the hydrolysate from the enzymatic saccharification process was performed using glucose oxidase/peroxidase and xylose dehydrogenase assays (Megazyme International, Wicklow, Ireland).

\section{Cell wall compositional analysis}

The biomass composition (glucan, xylan, galactan, arabinan, lignin, and ash) was determined by following the NREL Laboratory Analytical Procedure (LAP): Determination of Structural Carbohydrates and Lignin in Biomass (NREL/TP-510-42618). NREL LAPs are available online [43].

\section{Lignin characterization}

A commercially available molecular beam mass spectrometer modified for biomass analysis was used for 
pyrolysis vapor analysis [44-46]. Approximately $4 \mathrm{mg}$ of air-dried, 20-mesh biomass was pyrolyzed at $500{ }^{\circ} \mathrm{C}$. Mass spectral data from $\mathrm{m} / z \quad 30-450$ were acquired using $17 \mathrm{eV}$ electron impact ionization. S/G ratios were estimated by summing the syringyl peaks $154,167,168$, $182,194,208$, and 210 and dividing by the sum of guaiacyl peaks 124, 137, 138, 150, 164, and 178 [44]. Several lignin peaks were omitted in the syringyl or guaiacyl summations due to individual peaks having associations with both $\mathrm{S}$ and $\mathrm{G}$ precursors [44]. Thioacidolysis for analyzing $\mathrm{S}, \mathrm{G}$, and $\mathrm{H}$ monomer content was performed according to the procedure described in Foster et al. [47]. Thioacidolysis is used to determine the $\mathrm{H}$ monomer contribution due to the inability of the pyrolysis method to efficiently detect this monomer.

\begin{abstract}
Abbreviations
${ }^{13} \mathrm{C}-\mathrm{NMR}$ : carbon-13 nuclear magnetic resonance; $\mathrm{C} 3^{\prime} \mathrm{H}$ : $p$-coumaroyl quinate/ shikimate $3^{\prime}$-hydroxylase or $p$-coumarate 3-hydroxylase; $\mathrm{C} 4 \mathrm{H}$ : cinnamate 4-hydroxylaseCOMT-caffeic acid 3-O-methyltransferase; dCt: delta threshold value; ddCt: delta-delta threshold value; EC: Enzyme Commission; G: coniferyl alcohol; H: 4-coumaryl alcohol; HCT: shikimate hydroxycinnamoyl transferase; LAP: Laboratory Analytical Procedure; NREL: National Renewable Energy Laboratory; PyMBMS: pyrolysis molecular beam mass spectrometry; qPCR: quantitative polymerase chain reaction; RNAi: RNA interference; S: sinapyl alcohol.
\end{abstract}

\section{Authors' contributions}

$W R, M H$, and $M D$ designed the study. GT, AZ, EG, and SD provided sugar release/starch data collection and analysis. RS completed PyMBMS data collection and analysis. WR and SK performed the gene expression analyses. $\mathrm{KF}$ coordinated tree collections and processed plant material. CF provided thioacidolysis data and analysis. RS, EG, WR, and MD wrote the manuscript. All authors read and approved the manuscript.

\section{Author details \\ ${ }^{1}$ National Bioenergy Center, National Renewable Energy Laboratory, 15013 Denver West Parkway, Golden, CO 80401-3393, USA. ${ }^{2}$ Biosciences Center, National Renewable Energy Laboratory, 15013 Denver West Parkway, Golden, CO 80401-3393, USA. ${ }^{3}$ ArborGen Inc., 2011 Broadbank Ct., Ridgeville, SC 29472, USA. ${ }^{4}$ Great Lakes Bioenergy Research Center, Michigan State Univer- sity, East Lansing, MI 48824, USA.}

\section{Acknowledgements}

The authors acknowledge Richard Forster, Paul Sanders, Marie Connett, Clare Elton, Sandra Fitzgerald, and Gary Zhang for their contributions to the design and construction of the plasmids, Peter Richardson, Brian Kwan, and Marina Kalyaeva for the production and tissue culture of $\mathrm{CH}^{\prime} 3$ and $\mathrm{C} 4 \mathrm{H}$ transgenic eucalyptus lines, and Don Kaczmarek and Chris Judy for maintenance and measurement of the field test. The BioEnergy Science Center is a U.S. Department of Energy Bioenergy Research Center supported by the Office of Biological and Environmental Research in the DOE Office of Science. This work was supported by the U.S. Department of Energy under Contract No. DE-AC3608-GO28308 with the National Renewable Energy Laboratory.

\section{Compliance with ethical guidelines}

\section{Competing interests}

The authors declare that they have no competing interests.

Received: 21 April 2015 Accepted: 13 August 2015

Published online: 27 August 2015

\section{References}

1. Sanchez OJ, Cardona CA (2008) Trends in biotechnological production of fuel ethanol from different feedstocks. Bioresour Technol 99(13):52705295. doi:10.1016/j.biortech.2007.11.013

2. Himmel ME (2008) Biomass recalcitrance: deconstructing the plant cell wall for bioenergy. Blackwell, Oxford

3. Jeoh T, Ishizawa Cl, Davis MF, Himmel ME, Adney WS, Johnson DK (2007) Cellulase digestibility of pretreated biomass is limited by cellulose accessibility. Biotechnol Bioeng 98(1):112-122. doi:10.1002/bit.21408

4. Vega-Sanchez ME, Ronald PC (2010) Genetic and biotechnological approaches for biofuel crop improvement. Curr Opin Biotechnol 21(2):218-224. doi:10.1016/j.copbio.2010.02.002

5. Simmons BA, Logue D, Ralph J (2010) Advances in modifying lignin for enhanced biofuel production. Curr Opin Plant Biol 13(3):313-320. doi:10.1016/j.pbi.2010.03.001

6. Wyman CE (2007) What is (and is not) vital to advancing cellulosic ethanol. Trends Biotechnol 25(4):153-157. doi:10.1016/j.tibtech.2007.02.009

7. Chen F, Dixon RA (2007) Lignin modification improves fermentable sugar yields for biofuel production. Nat Biotechnol 25(7):759-761. doi:10.1038/nbt1316

8. Fu CX, Mielenz JR, Xiao XR, Ge YX, Hamilton CY, Rodriguez M et al (2011) Genetic manipulation of lignin reduces recalcitrance and improves ethanol production from switchgrass. Proc Natl Acad Sci USA 108(9):38033808. doi:10.1073/pnas.1100310108

9. Cook C, Devoto A (2011) Fuel from plant cell walls: recent developments in second generation bioethanol research. J Sci Food Agric 91(10):17291732. doi:10.1002/jsfa.4455

10. Mansfield SD, Kang KY, Chapple C (2012) Designed for deconstruction-poplar trees altered in cell wall lignification improve the efficacy of bioethanol production. New Phytol 194(1):91-101. doi:10.1111/j.1469-8137.2011.04031.x

11. Kaku T, Kaida R, Baba K, Hartati S, Sudarmonowati E, Hayashi T (2011) Improvement of fermentable sugar yields of mangium through transgenic overexpression of xyloglucanase. J Wood Sci. 57(6):545-548. doi:10.1007/s10086-011-1180-3

12. Sjoestrom E (1993) Wood chemistry: fundamentals and applications, 2nd edn. Academic Press, Oxford

13. Wadenback J, Clapham D, Gellerstedt G, von Arnold S (2004) Variation in content and composition of lignin in young wood of Norway spruce. Holzforschung 58(2):107-115. doi:10.1515/hf.2004.015

14. Ralph J, Akiyama T, Coleman HD, Mansfield SD (2012) Effects on lignin structure of coumarate 3-hydroxylase downregulation in poplar. Bioenergy Res 5(4):1009-1019. doi:10.1007/s12155-012-9218-y

15. Kumar R, Wyman CE (2010) Features of controlling hydrolysis of cellulose in pretreated biomass. In: Waldron K (ed) Bioalcohol production. Woodhead, Cambridge, pp 73-121

16. Kien ND, Quang TH, Jansson G, Harwood C, Clapham D, von Arnold S (2009) Cellulose content as a selection trait in breeding for kraft pulp yield in Eucalyptus urophylla. Ann For Sci. doi:10.1051/forest/2009064

17. Denis M, Favreau B, Ueno S, Camus-Kulandaivelu L, Chaix G, Gion JM et al (2013) Genetic variation of wood chemical traits and association with underlying genes in Eucalyptus urophylla. Tree Genet Genomes 9(4):927-942. doi:10.1007/s11295-013-0606-z

18. Kawaoka A, Nanto K, Ishii K, Ebinuma H (2006) Reduction of lignin content by suppression of expression of the LIM domain transcription factor in Eucalyptus camaldulensis. Silvae Genet 55(6):269-277

19. Bjurhager I, Olsson AM, Zhang B, Gerber L, Kumar M, Berglund LA et al (2010) Ultrastructure and mechanical properties of populus wood with reduced lignin content caused by transgenic down-regulation of cinnamate 4-hydroxylase. Biomacromolecules 11(9):2359-2365. doi:10.1021/ bm100487e

20. Bonawitz ND, Chapple C (2010) The genetics of lignin biosynthesis: connecting genotype to phenotype. In: Campbell A, Lichten M, Schupbach $\mathrm{G}$ (eds) Annual review of genetics, vol 44. Annual Reviews, Palo Alto, pp 337-363

21. Sattler SE, Palmer NA, Saballos A, Greene AM, Xin ZG, Sarath G et al (2012) Identification and characterization of four missense mutations in brown midrib 12 (Bmr12), the caffeic O-methyltranferase (COMT) of sorghum. Bioenergy Res 5(4):855-865. doi:10.1007/s12155-012-9197-z 
22. Yee $\mathrm{KL}$, Rodriguez $M$, Tschaplinski TJ, Engle NL, Martin MZ, Fu CX et al (2012) Evaluation of the bioconversion of genetically modified switchgrass using simultaneous saccharification and fermentation and a consolidated bioprocessing approach. Biotechnol Biofuels. doi:10.1186/1754-6834-5-81

23. O'Connell A, Holt K, Piquemal J, Grima-Pettenati J, Boudet A, Pollet B et al (2002) Improved paper pulp from plants with suppressed cinnamoylCoA reductase or cinnamyl alcohol dehydrogenase. Transgenic Res 11(5):495-503. doi:10.1023/a:1020362705497

24. Baucher M, Halpin C, Petit-Conil M, Boerjan W (2003) Lignin: genetic engineering and impact on pulping. Crit Rev Biochem Mol Biol 38(4):305-350. doi:10.1080/10409230390242443

25. Ralph J, Akiyama T, Kim H, Lu FC, Schatz PF, Marita JM et al (2006) Effects of coumarate 3-hydroxylase down-regulation on lignin structure. J Biol Chem 281(13):8843-8853. doi:10.1074/jbc.M511598200

26. Ziebell A, Gracom K, Katahira R, Chen F, Pu YQ, Ragauskas A et al (2010) Increase in 4-coumaryl alcohol units during lignification in alfalfa (Medicago sativa) alters the extractability and molecular weight of lignin. J Biol Chem 285(50):38961-38968. doi:10.1074/jbc.M110.137315

27. Reddy MSS, Chen F, Shadle G, Jackson L, Aljoe H, Dixon RA (2005) Targeted down-regulation of cytochrome P450 enzymes for forage quality improvement in alfalfa (Medicago sativa L.). Proc Natl Acad Sci USA 102(46):16573-16578. doi:10.1073/pnas.0505749102

28. Blee K, Choi JW, O'Connell AP, Jupe SC, Schuch W, Lewis NG et al (2001) Antisense and sense expression of CDNA coding for CYP73A15, a class II cinnamate 4-hydroxylase, leads to a delayed and reduced production of lignin in tobacco. Phytochemistry 57(7):1159-1166. doi:10.1016/ s0031-9422(01)00150-9

29. Carocha V, Soler M, Hefer CA, Cassan-Wang H, Fevereiro P, Myburg AA et al (2015) Genome-wide analysis of the lignin toolbox of Eucalyptus grandis. New Phytol 206(4):1-17. doi:10.1111/nph.13313

30. Decker S, Carlile M, Selig M, Doeppke C, Davis M, Sykes R et al (2012) Reducing the effect of variable starch levels in biomass recalcitrance screening. In: Himmel ME (ed) Biomass conversion. Methods in molecular biology. Humana Press, New York, pp 181-95. doi:10.1007/978-1-61779-956-3_17

31. Pu YQ, Chen F, Ziebell A, Davison BH, Ragauskas AJ (2009) NMR characterization of $\mathrm{C} 3 \mathrm{H}$ and $\mathrm{HCT}$ down-regulated alfalfa lignin. Bioenergy Res 2(4):198-208. doi:10.1007/s12155-009-9056-8

32. Selig M, Tucker M, Sykes R, Reichel K, Brunecky R, Himmel M et al (2010) Lignocellulose recalcitrance screening by integrated high-throughput hydrothermal pretreatment and enzymatic saccharification. Ind Biotechnol 6:104-111. doi:10.1089/ind.2010.0009

33. Decker SR, Brunecky R, Tucker MP, Himmel ME, Selig MJ (2009) Highthroughput screening techniques for biomass conversion. Bioenergy Res 2(4):179-192. doi:10.1007/s12155-009-9051-0

34. Bonawitz ND, Chapple C (2013) Can genetic engineering of lignin deposition be accomplished without an unacceptable yield penalty? Curr Opin Biotechnol 24(2):336-343. doi:10.1016/j.copbio.2012.11.004
35. Yang F, Mitra P, Zhang L, Prak L, Verhertbruggen Y, Kim JS et al (2013) Engineering secondary cell wall deposition in plants. Plant Biotechnol J 11(3):325-335. doi:10.1111/pbi.12016

36. Studer MH, DeMartini JD, Davis MF, Sykes RW, Davison B, Keller M et al (2011) Lignin content in natural Populus variants affects sugar release. Proc Natl Acad Sci USA 108(15):6300-6305. doi:10.1073/pnas.1009252108

37. Forster R, Rottmann W, Connett M, Sanders P, Zhang G, Fitzgerald S et al (2008) DNA construct comprising a promoter linked to gene involved in monolignol biosynthetic pathway. United States

38. Myburg AA, Grattapaglia D, Tuskan GA, Hellsten U, Hayes RD, Grimwood J et al (2014) The genome of Eucalyptus grandis. Nature 510(7505):356-362. doi:10.1038/nature13308

39. JGI. Phytozome 10.1 (2012) The JGl comparative plant genomics portal. http://phytozome.jgi.doe.gov/pz/eucalyptus. Accessed 3 Oct 2012

40. Goodstein DM, Shu SQ, Howson R, Neupane R, Hayes RD, Fazo J et al (2012) Phytozome: a comparative platform for green plant genomics. Nucleic Acids Res 40(D1):D1178-D1186. doi:10.1093/nar/gkr944

41. Tournier V, Grat S, Marque C, El Kayal W, Penchel R, de Andrade G et al (2003) An efficient procedure to stably introduce genes into an economically important pulp tree (Eucalyptus grandis $\times$ Eucalyptus urophylla). Transgenic Res 12(4):403-411. doi:10.1023/a:1024217910354

42. Untergasser A, Cutcutache I, Koressaar T, Ye J, Faircloth BC, Remm M et al (2012) Primer3-new capabilities and interfaces. Nucleic Acids Res 40(15):e115. doi:10.1093/nar/gks596

43. Sluiter A, Hames B, Ruiz R, Scarlata C, Sluiter J, Templeton D et al (2012) Determination of structural carbohydrates and lignin in biomass. NREL Laboratory Analytical Procedures 2012. http://www.nrel.gov/docs/gen/ fy13/42618.pdf Accessed 14 Sept 2012

44. Sykes R, Yung M, Novaes E, Kirst M, Peter G, Davis M (2009) High-throughput screening of plant cell-wall composition using pyrolysis molecular beam mass spectroscopy. In: Mielenz J (ed) Biofuels: methods and protocols, methods in molecular biology. Humana Press, New York, pp 169-183. doi:10.1007/978-1-60761-214-8_12

45. Evans RJ, Milne TA (1987) Molecular characterization of the pyrolysis of biomass. Fund Energy Fuels 1(2):123-137. doi:10.1021/ef00002a001

46. Tuskan G, West D, Bradshaw HD, Neale D, Sewell M, Wheeler N et al (1999) Two high-throughput techniques for determining wood properties as part of a molecular genetics analysis of hybrid poplar and loblolly pine. Appl Biochem Biotechnol 77-9:55-65. doi:10.1385/abab:77:1-3:55

47. Foster C, Martin T, Pauly M (2010) Comprehensive compositional analysis of plant cell walls (lignocellulosic biomass) part I: lignin. J Vis Exp 37:e1745

\section{Submit your next manuscript to BioMed Central and take full advantage of:}

- Convenient online submission

- Thorough peer review

- No space constraints or color figure charges

- Immediate publication on acceptance

- Inclusion in PubMed, CAS, Scopus and Google Scholar

- Research which is freely available for redistribution

Submit your manuscript at 